\title{
Aneuploidy in Workers Occupationally Exposed to Electromagnetic Field Detected by FISH
}

\author{
Othman El Mahdy Sayed Othman ${ }^{1, *}$, Magdy Sayed Aly², \\ and Soheir Mohamed EI Nahas ${ }^{1}$ \\ ${ }^{1}$ Cell Biology Department, National Research Center, Dokki, Egypt. \\ ${ }^{2}$ Zoology Department, Faculty of Science, Cairo University (Beni-Suef branch), Egypt.
}

Accepted September 8, 2000

\begin{abstract}
Summary Exposure to power frequency electromagnetic fields (EMF) may cause adverse health effects in humans. Some epidemiological studies support an association between exposure to EMF and the incidence of different types of cancer, which may be associated with the presence of chromosomal aneuploidy. In this study, fluorescence in situ hybridization (FISH) was used to detect numerical chromosomal aberrations induced by occupational exposure to EMF. The labeled probes used in this study were repetitive $\alpha$-satellite probes for chromosomes 7, 12, 17 and heterochromatic region of the Y chromosome. This study was conducted using 23 male individuals, 18 of which are occupationally exposed to EMF whereas the other 5 individuals are used as controls. Our study shows monosomy of chromosomes 7 and 17 in 4 and 3 exposed individuals, respectively. The mean percentages of nuclei with monosomy of chromosomes 7 and 17 in these affected individuals are $18.3 \%$ and $16.1 \%$, respectively. The loss of $Y$ chromosome was detected in 6 exposed individuals and the mean percentage of nuclei showing this aberration is $15.8 \%$. In control individuals, the mean percentages of nuclei with monosomy of chromosomes 7, 17 and loss of the $\mathrm{Y}$ chromosome were $3.2 \%$, $3.7 \%$ and $4.5 \%$, respectively. The increase in monosomy of chromosomes 7 and 17 and the loss of $Y$ chromosome compared to the control is statistically significant $(P<0.001)$. No significant increase in numerical aberrations of chromosome 12 was observed in exposed individuals.
\end{abstract}

Key words EMF exposure, Aneuploidy, FISH.

There is growing concern that environmental and household exposure to power frequency electric and/or magnetic fields may cause adverse health effects in humans. Several epidemiological studies indicate an association between exposure to magnetic fields, in residential or occupational environments, and the incidence of cancer (Lin et al. 1985, Savitz and Calle 1987, Thomas et al. 1987, Savitz et al. 1988, Dennis et al. 1991, London et al. 1991, Theriault 1991). The cancers most frequently identified are acute leukemia and brain cancers.

A number of investigations have been carried out to test the potential genotoxicity of electric and magnetic fields. Several reviews on the genotoxic and carcinogenic potential of EMF studies have appeared (Michaelson 1987, Scarfi et al. 1989, McCann et al. 1993, 1998). Because initiation of carcinogenesis is believed to involve DNA damage, assays for genotxicity are considered to supply evidence relevant to carcinogenic potential (Dennis et al. 1991).

Controversy still exists on the genetic effect of electromagnetic fields. Several studies reported the mutagenic effect of EMF, including increase in chromosome and chromatid abnormalities, sister chromatid exchanges and also micronuclei formation in both in vivo and in vitro studies on human peripheral lymphocytes and other mammalian cells (Nordenson et al. 1984, 1988, 1994, Butler et al. 1987, Rosenthal and Obe 1989, El Nahas and Oraby 1989, Khalil and Qassem 1991, Tofani et al. 1995, Miyakoshi et al. 1996, 1997).

However in other studies, these same end points were negative (Bauchinger et al. 1981, Cohen

\footnotetext{
* Corresponding author.
} 
et al. 1986, Livingston et al. 1991, Takahashi et al. 1987, Rosenthal and Obe 1989, Garcia-Sagredo et al. 1990, Saalman et al. 1991, Scarfi et al. 1991, Hintenlang 1993, Tabrah et al. 1994, Antonopoulos et al. 1995, Galt et al. 1995, Paile et al. 1995). From the carcinogenic effect point of view, these negative results suggest that EMF may not have potential as an initiator of carcinogenesis (Livingston et al. 1991). Most recent research on the question of a causal role of EMF in the development of cancer has focused on the later stages of carcinogenesis and cancer development, namely promotion and progression (McCann et al. 1993).

The objective of this study is to assess whether occupational electromagnetic field exposure is a risk factor for the induction of aneuploidy damage using fluorescence in situ hybridization technique to interphase nuclei in stimulated blood lymphocyte cultures.

\section{Materials and methods}

The present study includes 18 male air traffic controllers and engineers who have been exposed for 10-27 years to electromagnetic fields emitted from radar screens, antennae, satellite installations and closed circuit televisions (CCTV). All worked in shifts of $6 \mathrm{~h}$ period and they rotated clockwise changing their shift every day with a night shift of $12 \mathrm{~h}$ which was followed by 2 days off. Also, 5 comparable males randomly chosen were used as a control group, matched for age, smoking habits and socio-economic status, none of them had been occupationally exposed to EMF. None of the workers under investigation nor the control group had been exposed to known chromosomedamaging agents, including drugs, nor they received ionizing radiation for medical purposes except for occasional chest roentgenograms.

\section{Cell cultures}

Peripheral blood lymphocytes from EMF exposed and non exposed individuals were cultured at $37^{\circ} \mathrm{C}$ for $72 \mathrm{~h}$ in $5 \mathrm{ml}$ of RPMI 1640 medium (Gibco) containing $20 \%$ foetal calf serum (Gibco), $0.1 \%$ garamycin (Schering), 1\% L-glutamine (Flow) and 4\% phytohaem-agglutinin (Wellcome). Slides were prepared for the analysis of interphase nuclei according to standard cytogenetic protocols including hypotonic swelling with $0.075 \mathrm{M} \mathrm{KCl}$ and 3 times fixation with methanol : acetic acid $(3: 1)$.

\section{Probe labeling and fluorescence in situ hybridization}

The 3 human $\alpha$-satellite DNA specific for the peri-centromeric regions of chromosomes 7, 12, 17 and the heterochromatic region of the $\mathrm{Y}$ chromosome [which detect the 2.1-Kb repeat of the heterochromatic region of the $Y_{\mathrm{q}}$ arm (pHY2.1) (Cooke et al. 1982)] were used. The probes were labeled by nick-translation using biotin-11-dUTP according to BRL protocol.

The labeled DNA was ethanol-precipitated with salmon sperm DNA. The precipitate was dissolved in $60 \%$ formamide $/ 2 \times \mathrm{SSC}(1 \times \mathrm{SSC}=0.15 \mathrm{M} \mathrm{NaCl}, 0.015 \mathrm{M}$ sodium citrate $)$ to a probe concentration of $2.5 \mathrm{ng} / \mu 1$.

FISH was performed according to the protocol of Kievits et al. (1990) with some modifications. Briefly, the slides were treated with RNase A for $1 \mathrm{~h}$ at $37^{\circ} \mathrm{C}(10 \mu \mathrm{g}$ in $100 \mu \mathrm{l}$ of $2 \times \mathrm{SSC}$ under $24 \times 50 \mathrm{~mm}^{2}$ coverslip) followed by pepsin treatment for $10 \mathrm{~min}$ at $37^{\circ} \mathrm{C}(0.01 \%$ pepsin $\{$ Serva $\}$ in $0.01 \mathrm{M} \mathrm{HCl}$ ), postfixed for $10 \mathrm{~min}$ in $1 \%$ acid-free formaldehyde in PBS, and then dehydrated in an ethanol series at room temperature. The probe and the target DNA were denatured simultaneously for $10 \mathrm{~min}$ at $75^{\circ} \mathrm{C}$.

Hybridization was performed overnight at $37^{\circ} \mathrm{C}$ in a humid chamber. Posthybridization washings were carried out at $45^{\circ} \mathrm{C}$ in $50 \%$ formamide, $2 \times \mathrm{SSC}(\mathrm{pH} 7.0) 3$ times for 2 min each, followed by $2 \times \mathrm{SSC}(\mathrm{pH} 7.0)$ once at room temperature for $2 \mathrm{~min}$. The slides were immersed in blocking buffer and were never allowed to dry after this point. 


\section{Signal detection}

The slides were incubated at room temperature with FITC conjugated avidin $(5 \mu \mathrm{g} / \mathrm{ml}$ in $4 \times$ SSC, $5 \%$ nonfat dry milk). The intensity of biotin-linked fluorescence was amplified by adding a layer of biotinylated goat anti-avidin antibody ( $5 \mu \mathrm{g} / \mathrm{ml}$ in $4 \times \mathrm{SSC}, 5 \%$ nonfat dry milk), followed, after washing, by another application of FITC conjugated avidin. Slides were dehydrated and mounted in antifade medium (9 parts glycerol containing 2.3\% DABCO $\{$ Sigma $\}: 1$ part $0.2 \mathrm{M}$ Tris- $\mathrm{HCl}, 0.02 \% \mathrm{NaN}_{3}, \mathrm{pH} 7.5$ ) containing DAPI of $0.5 \mu \mathrm{g} / \mathrm{ml}$ as chromosomal counterstain.

The evaluation of FISH results with the centromeric probes used was done according to criteria described previously (van Dekken et al. 1990a). One thousand intact and non-overlapping interphase nuclei were analyzed. The number of bright fluorescing spots per nucleus was scored for each probe with the signals having more or less the same homogenous fluorescence intensity. Minor hybridization spots were not counted. Spots in a paired arrangement (split spots) were counted as one signal.

\section{Statistical analysis}

For each probe, the significant differences between the signals/nucleus distributions obtained in both exposed and control groups, was determined using the chi-square test whereas significant differences between the personal characteristics were determined using the $t$-test.

\section{Results}

Statistical analysis was conducted to determine if there are significant differences in personal characteristic habits between EMF exposed and the control groups (Table 1). No statistically significant difference was found regarding their age and smoking habits. The median age of the exposed

Table 1. Personal characteristic of the exposed and control individuals

\begin{tabular}{|c|c|c|c|c|c|}
\hline Subject & $\begin{array}{l}\text { Case } \\
\text { No. }\end{array}$ & $\begin{array}{c}\text { Age } \\
\text { (years) }\end{array}$ & $\begin{array}{c}\text { Marital } \\
\text { status }\end{array}$ & $\begin{array}{c}\text { Smoking } \\
\text { habit }\end{array}$ & $\begin{array}{c}\text { Duration of } \\
\text { exposure to EMF } \\
\text { (years) }\end{array}$ \\
\hline \multirow{18}{*}{$\begin{array}{c}\text { Exposed } \\
\text { individuals }\end{array}$} & 1 & 51 & Married & Non-smoker & 25 \\
\hline & 2 & 45 & Married & Non-smoker & 17 \\
\hline & 3 & 52 & Married & smoker & 14 \\
\hline & 4 & 52 & Married & Non-smoker & 17 \\
\hline & 5 & 52 & Married & Non-smoker & 23 \\
\hline & 6 & 44 & Married & smoker & 20 \\
\hline & 7 & 36 & Single & Non-smoker & 10 \\
\hline & 8 & 42 & Married & smoker & 16 \\
\hline & 9 & 44 & Married & smoker & 20 \\
\hline & 10 & 52 & Married & Non-smoker & 23 \\
\hline & 11 & 51 & Married & Non-smoker & 27 \\
\hline & 12 & 49 & Married & Non-smoker & 15 \\
\hline & 13 & 44 & Married & Non-smoker & 17 \\
\hline & 14 & 45 & Married & smoker & 16 \\
\hline & 15 & 45 & Married & Non-smoker & 20 \\
\hline & 16 & 44 & Married & smoker & 19 \\
\hline & 17 & 43 & Married & Non-smoker & 15 \\
\hline & 18 & 42 & Single & Non-smoker & 15 \\
\hline \multirow[t]{5}{*}{ Controls } & 1 & 44 & Married & Non-smoker & ------- \\
\hline & 2 & 49 & Married & Non-smoker & -------- \\
\hline & 3 & 40 & Married & smoker & ------- \\
\hline & 4 & 39 & Single & smoker & -------- \\
\hline & 5 & 51 & Single & Non-smoker & -------- \\
\hline
\end{tabular}


Table 2 Evaluation of aneuploidy detected in lymphocyte cultures of exposed and control individuals after FISH with four biotinylated probes on interphase nuclei

\begin{tabular}{|c|c|c|c|c|c|c|}
\hline Subject & $\begin{array}{l}\text { Case } \\
\text { No. }\end{array}$ & $\begin{array}{l}\text { No. of } \\
\text { examined } \\
\text { cells }\end{array}$ & $\begin{array}{l}\text { No. and (\%) of } \\
\text { nuclei with } \\
\text { monosomy of } \\
\text { chromosome } 7\end{array}$ & $\begin{array}{l}\text { No. and }(\%) \text { of } \\
\text { nuclei with } \\
\text { monosomy of } \\
\text { chromosome } 12\end{array}$ & $\begin{array}{l}\text { No. and }(\%) \text { of } \\
\text { nuclei with } \\
\text { monosomy of } \\
\text { chromosome } 17\end{array}$ & $\begin{array}{l}\text { No. and }(\%) \text { of } \\
\text { nuclei with } \\
\text { loss of } Y \\
\text { chromosome }\end{array}$ \\
\hline Exposed & 1 & 1000 & $29(2.9)$ & $40(4.0)$ & $40 \quad(4.0)$ & $45 \quad(4.5)$ \\
\hline \multirow[t]{17}{*}{ individuals } & 2 & 1000 & $194(19.4)$ & $45(4.5)$ & $38 \quad(3.8)$ & $196(19.6)$ \\
\hline & 3 & 1000 & 31 & $37(3.7)$ & $46 \quad(4.6)$ & $52 \quad(5.2)$ \\
\hline & 4 & 1000 & $38 \quad(3.8)$ & $33(3.3)$ & $160(16.0)$ & $149(14.9)$ \\
\hline & 5 & 1000 & $182(18.2)$ & $39(3.9)$ & $40 \quad(4.0)$ & $145(14.5)$ \\
\hline & 6 & 1000 & $39 \quad(3.9)$ & $40(4.0)$ & $33 \quad(3.3)$ & $49 \quad(4.9)$ \\
\hline & 7 & 1000 & $26 \quad(2.6)$ & $36(3.6)$ & $48 \quad(4.8)$ & $39 \quad(3.9)$ \\
\hline & 8 & 1000 & $28 \quad(2.8)$ & $46(4.6)$ & $179(17.9)$ & $150(15.0)$ \\
\hline & 9 & 1000 & $190(19.0)$ & $44(4.4)$ & $42 \quad(4.2)$ & $47 \quad(4.7)$ \\
\hline & 10 & 1000 & $32(3.2)$ & $35(3.5)$ & $45 \quad(4.5)$ & $50 \quad(5.0)$ \\
\hline & 11 & 1000 & $30 \quad(3.0)$ & $33(3.3)$ & $39 \quad(3.9)$ & $46 \quad(4.6)$ \\
\hline & 12 & 1000 & $31 \quad(3.1)$ & $39(3.9)$ & $43 \quad(4.3)$ & $47 \quad(4.7)$ \\
\hline & 13 & 1000 & $27(2.7)$ & $37(3.7)$ & $145(14.5)$ & $163(16.3)$ \\
\hline & 14 & 1000 & $32(3.2)$ & $40(4.0)$ & $40 \quad(4.0)$ & $50 \quad(5.0)$ \\
\hline & 15 & 1000 & $165(16.5)$ & $35(3.5)$ & $37 \quad(3.7)$ & $45 \quad(4.5)$ \\
\hline & 16 & 1000 & $36(3.6)$ & $46(4.6)$ & $35 \quad(3.5)$ & $46 \quad(4.6)$ \\
\hline & 17 & 1000 & $38 \quad(3.8)$ & $39(3.9)$ & $39 \quad(3.9)$ & $43 \quad(4.3)$ \\
\hline & 18 & 1000 & $43 \quad(4.3)$ & $32(3.2)$ & $47 \quad(4.7)$ & 147 (14.7) \\
\hline \multirow[t]{5}{*}{ Controls } & 1 & 1000 & $38 \quad(3.8)$ & $38(3.8)$ & $40 \quad(4.0)$ & $47 \quad(4.7)$ \\
\hline & 2 & 1000 & $35 \quad(3.5)$ & $36(3.6)$ & $39 \quad(3.9)$ & $52 \quad(5.2)$ \\
\hline & 3 & 1000 & $32(3.2)$ & $39(3.9)$ & $34 \quad(3.4)$ & $46 \quad(4.6)$ \\
\hline & 4 & 1000 & $25 \quad(2.5)$ & $47(4.7)$ & $30 \quad(3.0)$ & $39 \quad(3.9)$ \\
\hline & 5 & 1000 & 30 & $45(4.5)$ & $43 \quad(4.3)$ & $43 \quad(4.3)$ \\
\hline
\end{tabular}

workers was 46.3 years (range 36-52 years) and the median age of control individuals was 44.6 years (range 39-51).

After establishing the proper conditions for signal analysis, the same conditions and probe concentrations were used for hybridization of the 4 probes to interphase nuclei of both exposed and control individuals. FISH was successful in all cases studied. Table 2 presents the number and percentages of signals for the 4 probes in exposed and control individuals. Only monosomy of chromosome 7 and 17 and loss of the $\mathrm{Y}$ chromosome was detected. It is known that specimen was considered monosomic if the percentage of nuclei exceeds $10 \%$. This same percentage applies for loss of chromosome Y (van Dekken et al. 1990b). Ten out of the 18 exposed cases had normal diploid chromosome count. Four cases $(22.2 \%$ of exposed individuals) demonstrated a loss of chromosome 7 (Fig. 1) and the percentages of nuclei showing monosomy 7 ranged from 16.5-19.4\% compared to $3.2 \%$ in control (mean value). In 2 cases (nos. 2, 5), monosomy of chromosome 7 was accompanied by loss of $\mathrm{Y}$ chromosome. Loss of chromosome 17 was detected in 3 cases (16.7\%) (Fig. 2). The percentages of nuclei showed monosomy 17 ranged from $14.5-17.9 \%$ with a mean of $16.1 \%$ compared to $3.7 \%$ in the control. Monosomy of chromosome 17 was accompanied by loss of $\mathrm{Y}$ chromosome in the 3 cases.

In 6 cases $(33.3 \%)$, a loss of $\mathrm{Y}$ chromosome was observed. The percentages of nuclei, which showed the loss of Y chromosome ranged from $14.5-19.6 \%$ with a mean of $15.8 \%$, compared to $4.5 \%$ in the control. As mentioned earlier, the loss of $\mathrm{Y}$ chromosome in 5 cases were accompanied by a loss of 7 or 17 chromosomes.

The increase in monosomy of chromosomes 7 and 17 and the loss of Y chromosome compared to the control were statistically significant at $P<0.001$. No significant numerical aberrations of 

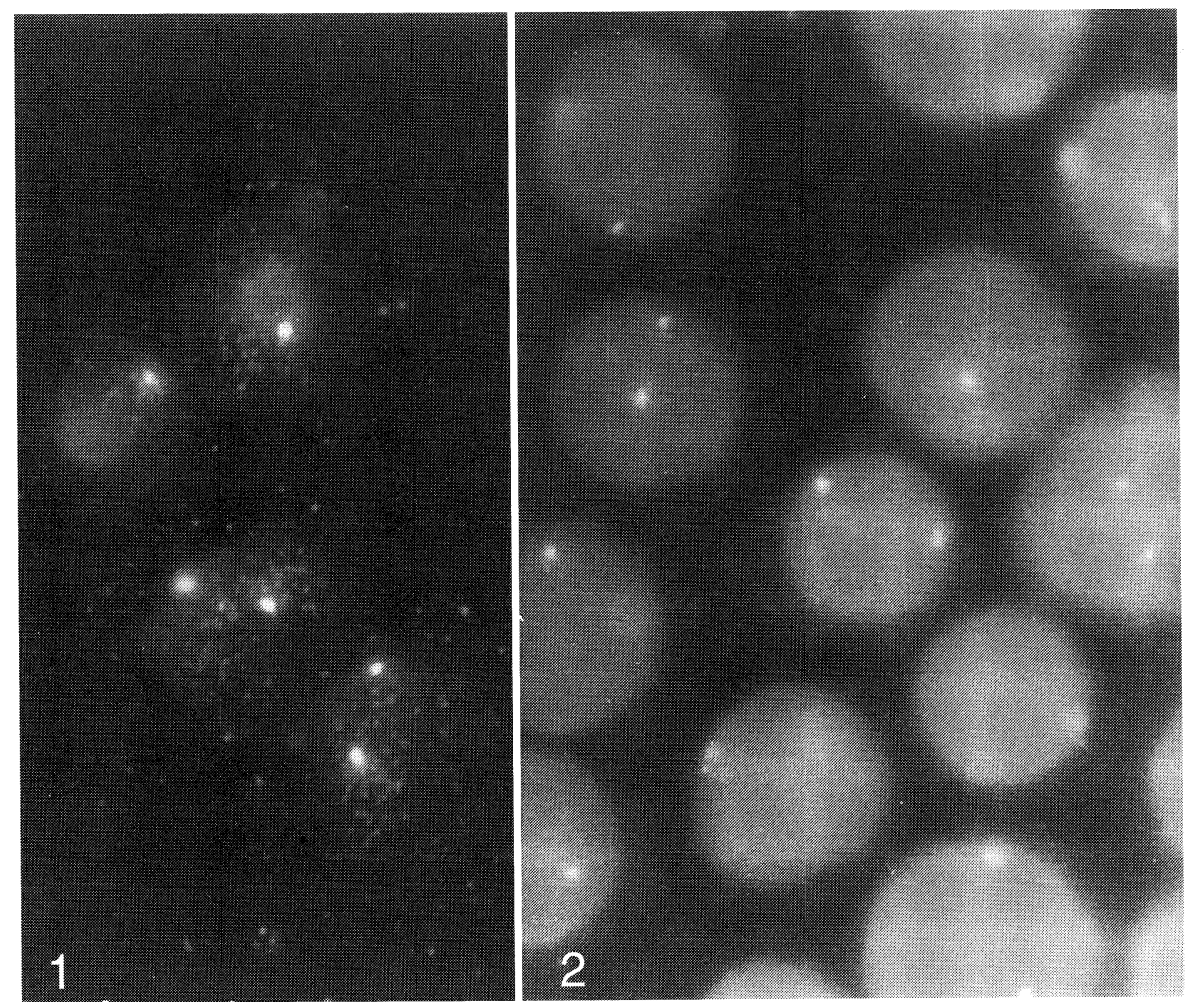

Figs. 1-2. 1) Fluorescence in situ hybridization with chromosome 7-specific alpha satellite DNA probe. Nuclei in the photomicrographs exhibit 1 and 2 centromeric spots. Omega double filter was used for the visualization of FITC only. 2) Fluorescence in situ hybridization with chromosome 17-specific alpha satellite DNA probe. Nuclei in the photomicrographs exhibit 1 and 2 centromeric spots. The used filter was specific for the visualization of FITC and DAPI.

chromosome 12 were observed in all exposed individuals tested. The mean percentage of nuclei with monosomy 12 in exposed individuals was 3.9\% compared to $4.1 \%$ in the control.

Neither age of workers and smoking habits nor the duration of exposure to EMF for more than 10 years had a statistically significant correlation with the presence or absence of any of the numerical chromosomal aberrations observed in this study.

\section{Discussion}

The controversy still exists on the genetic effect of electromagnetic fields. Although some reports concerning DNA damage and mutagenic effects of EMF show negative results (Zwingelberg et al. 1993, Murphy et al. 1993, McCann et al. 1993, 1998, Scarfi et al. 1994), others are reporting positive effects (Miyakoshi et al. 1996, 1997, El Nahas and Oraby 1989, Nordenson et al. 1994).

Several epidemiological studies have correlated exposure of human to electromagnetic fields with a high incidence of cancer (Coleman et al. 1983, McDowall 1983, Milham 1985, Pearce et al. 1985, Speers et al. 1988, Loscher et al. 1993, Loscher and Mevissen 1994).

Hardell et al. (1995) and McCann et al. (1997) suggest that experimental evidence seems to exclude the possibility of an initiating carcinogenic effect of EMF but promoting effects are possible, one of these could be stimulation of the cell cycle. Extensive efforts are now underway to assess the carcinogenic potential of EMF in animal model systems. Specific numerical chromosomal aberrations play an important and possibly essential role in neoplastic development. 
The present study shows monosomy of chromosomes 7 in $22.2 \%$ of exposed individuals and monosomy of chromosome 17 in $16.7 \%$ of exposed individuals. Six exposed individuals (33.3\%) showed loss of $\mathrm{Y}$ chromosome. The percentage of signals in individual with monosomy 7,17 and loss of $\mathrm{Y}$ chromosome ranged from 14.5-19.6\%. It is known that specimen was considered monosomic if the percentage of nuclei exceeds $10 \%$. This same percentage applies for loss of chromosome Y (van Dekken et al. 1990b). The increase in monosomy of chromosomes 7 and 17 and the loss of $Y$ chromosome compared to the control were statistically significant at $p<0.001$. No numerical aberrations of chromosome 12 were observed in all exposed individuals tested. Loss of chromosome $\mathrm{Y}$ was accompanied by monosomy 7 in 2 cases and by monosomy 17 in 3 cases. Loss of $\mathrm{Y}$ chromosome has been reported to be accompanied by other karyotypic abnormalities (van Dekken and Alers 1993, Aly et al. 1993).

The monosomy of chromosomes 7 and 17 and the loss of Y chromosome observed in the present study, may shed some light on the relation between the exposure to EMF and the incidence of cancer.

Chromosomal loss is the most frequent karyotypic abnormality in the myelodysplastic syndromes (Boultwood and Fidler 1995). Recent attention has focused on the loss of genetic material as a result of chromosomal monosomy or deletion in the myelodysplastic syndromes. The most frequently reported deletions in these myeloid syndromes are of chromosome 7 (Wyandt et al. 1998). It is probable that the deleted chromosomal bands involve the location for the unidentified myeloid specific tumor suppressor loci (Boultwood and Fidler 1995). Loss of a chromosome 7 is also associated with a poor prognosis in acute myeloid leukemia (Kadam et al. 1993, Fischer et al. 1996, Pedersen et al. 1997).

As for chromosome 17, the gene for p53, neu (c-erbB-2) and nm23 are all located on this chromosome. Abnormality of chromosome 17, and in particular the loss of parts of the short arm, had previously been related as characteristic in disorders such as blast crisis of chronic myeloid leukemia (Borgstrom et al. 1982) and acute myeloblastic leukemia de-novo (Fourth International Workshop on Chromosomes in Leukemia 1984). Numerical aberrations of chromosome 17 have been frequently observed also in many other tumor types and often as a secondary change such as multiple myeloma (Drach et al. 1995), colorectal carcinoma (Wang et al. 1997), breast carcinoma cells (Sauer et al. 1998), ovarian carcinomas (Diebold 1999), chromophobe renal cell carcinoma (Gunawan et al. 1999), and primary gastric cancers (Terada et al. 1999).

Loss of Y chromosome was found to be a normal aging phenomenon in bone marrow cells of elder men (Pierre and Hoagland 1971, 1972). However, Y chromosome loss may not be entirely related to aging and the possibility remains that, at least in an occasional cases, cells with a missing $\mathrm{Y}$ may be neoplastic (Aly et al. 1993). Loss of Y chromosome was reported as a sole anomaly in many malignant as well as benign tumors (Mitelman 1991).

From our results we can conclude that exposure to EMF lead to significant chromosomal aneuploidy in chromosomes 7 and 17 which are reported in cancer cases. Also, loss of Y chromosome reported here reflect an increase in the rate of aging at least at the cellular level in addition to its role in some cancers. In view of these findings and the contradictory reports in the literatures, it is important to carry out more investigations using various types of cells under different experimental conditions to resolve the controversy concerning the possible risks associated with EMF. It is therefore recommended that exposure to EMF should be minimized through increasing exposure distance between the workers and the functioning units and shielding through the use of electricityproof materials. Regular monitoring of the work place for both electric and magnetic fields is mandatory. 


\section{References}

Aly, M. S., Dal Cin, P., Moerman, P. H., De Wever, I., Devriendt, K., Brock, P., Casteels-Van Daele, M. and Van den Berghe, H. 1993. Loss of the Y chromosome in a malignant Sertoli tumor. Cancer Genet. Cytogenet. 65: 104-106.

Antonopoulos, A., Yang, B., Stamm, A., Heller, W. D. and Obe, G. 1995. Cytological effects of $50 \mathrm{~Hz}$ electromagnetic fields on human lymphocytes in vitro. Mutat. Res. 346: 151-157.

Bauchinger, M., Hauf, R., Schmid, E. and Dresp, J. 1981. Analysis of structural chromosomal changes and SCE after occupational long-term exposure to electric and magnetic fields from $380 \mathrm{KV}$-systems. Radiat. Environ. Biophys. 19: 235-238.

Borgstrom, G. H., Vuopio, P. and de la Chapelle, A. 1982. Abnormalities of chromosome no 17 in myeloproliferative disorders. Cancer Genet. Cytogenet. 5: 123-135.

Boultwood, J. and Fidler, C. 1995. Chromosomal deletions in myelodysplasia. Leuk. Lymphoma 17: 71-78.

Butler, M. G., Yost, J. and Jenkins, B. B. 1987. Chromosome breakage and sister chromatid exchanges analysis in computer operators. J. Environ. Sci. Health. A22: 729-741.

Cohen, M. M., Kunska, A., Astemborski, J., McCulloch, D. and Paskewitz, D. 1986. Effects of low-level 60-Hz electromagnetic fields on human lymphoid cells. I. Mitotic rate and chromosome breakage in human peripheral lymphocytes. Bioelectromagnetics. 7: 415-423.

Coleman, M., Bell, J. and Skeet, R. 1983. Leukemia incidence in electrical workers. Lancet 1: 982-983.

Cooke, H. J., Schmiddke, J. and Gosden, J. R. 1982. Characterization of a human Y chromosome repeated sequence and related sequences in higher primates. Chromosoma 87: 491-502.

Dennis, J. A., Muirhead, C. R. and Ennis, J. R. 1991. Epidemiological studies of exposure to electromagnetic fields II cancer. J. Radiol. Prot. 11: 13-25.

Diebold, J. 1999. Molecular genetics of ovarian carcinomas. Histol. Histopathol. 14: 269-277.

Drach, J., Schuster, J., Nowotny, H., Angerler, J., Rosenthal, F., Fiegl, M., Rothermundt, C., Gsur, A. and Jager, U. 1995. Multiple myeloma: high incidence of chromosomal aneuploidy as detected by interphase fluorescence in situ hybridization. Cancer Res. 55: 3854-3859.

El Nahas, S. M. and Oraby, H. A. 1989. Micronuclei formation in somatic cells of mice exposed to $50-\mathrm{Hz}$ electric fields. Environ. Mol. Mutagen. 13: 107-111.

Fischer, K., Scholl, C., Salat, J., Frohling, S., Schlenk, R., Bentz, M., Stilgenbauer, S., Lichter, P. and Dohner, H. 1996. Design and validation of DNA probe sets for a comprehensive interphase cytogenetic analysis of acute myeloid leukemia. Blood 88: 3962-3971.

Fourth International Workshop on Chromosomes in Leukemia 1984. Cancer Genet. Cytogenet. 11: 249-360.

Galt, S., Wahlstrom, J., Hamnerius, Y., Holmqvist, D. and Johannesson, T. 1995. Study of effects of $50 \mathrm{~Hz}$ magnetic fields on chromosome aberrations and the growth-related enzyme ODC in human amniotic cells. Bioeletrochem. Bioenergetics. 36: 1-8.

Garcia-Sagredo, J. M., Parada, L. A. and Monteagudo, J. L. 1990. Effects on SCE in human chromosomes in vitro of lowlevel pulsed magnetic field. Environ. Mol. Mutagen. 16: 185-188.

Gunawan, B., Bergmann, F., Braun, S., Hemmerlein, B., Ringert, R.H., Jakse, G. and Fuzesi, L. 1999. Polyploidization and losses of chromosomes 1, 2, 6, 10,13, and 17 in three cases of chromophobe renal cell carcinomas. Cancer Genet. Cytogenet. 100: 57-61.

Hardell, L., Holmberg, B., Malker, H. and Paulsson, L. E. 1995. Exposure to extremely low frequency electromagnetic fields and the risk of maliggnant diseases-an evaluation of epidemiological and experimental findings. Eur. J. Cancer Prev. 4: 3-107.

Hintenlang, D. E. 1993. Synergistic effects of ionizing radiation and $60 \mathrm{~Hz}$ magnetic fields. Bioelectromagnetics 14: 545-551.

Kadam, P., Umerani, A., Srivastava, A., Masterson, M., Lampkin, B. and Raza, A. 1993. Combination of classical and interphase cytogenetics to investigate the biology of myeloid disorders: detection of masked monosomy 7 in AML. Leuk. Res. 17: 365-374.

Khalil, A. M. and Qassem, W. 1991. Cytogenetic effects of pulsing electromagnetic field on human lymphocytes in vitro: chromosome aberrations, sister chromtid exchanges and cell kinetics. Mutat. Res. 247: 141-146.

Kievits, T., Dauwerse, J. G., Wiegant, J. and Pearson, P. L. 1990. Rapid subchromosomal localization of cosmids by non-radioactive in situ hybridization. Cytogenet. Cell Genet. 53: 134-136.

Lin, R. S., Dischinger, P. C., Conde, J. and Farrell, K. P. 1985. Occupational exposure to electromagnetic fields and the occurrence of brain tumors. An analysis of possible association. J. Occup. Med. 27: 413-419.

Livingston, G. K., Witt, K. L., Gandhi, O. P., Chatterjee, I. and Roti, J. L. R. 1991. Reproductive integrity of mammalian cells exposed to power frequency electromagnetic fields. Environ. Mol. Mutagen. 17: 49-58.

London, S. J., Thomas, D. C., Bowman, J. D., Sobel, E., Cheng, T. C. and Peters, J. M. 1991. Exposure to residential electric and magnetic fields and risk of childhood leukemia. Am. J. Epidemiol. 134: 923-937. 
Loscher, W. and Mevissen, M. 1994. Animal studies on the role of 50/60-Hertz magnetic fields in carcinogenesis. Life Sci. 54: 1531-1543.

- , - Lehmacher, W. and Stamm, A. 1993. Tumor promotion in a brreast cancer model by exposure to a weak alternating magnetic field. Cancer Lett. 71: 75-81.

McCann, J., Dietrich, F. and Rafferty, C. 1998. The genotoxic potential of electric and magnetic fields: an update. Mutat. Res. 411: 45-86.

- - - - - and Martin, A. O. 1993. A critical review of the genotoxic potential of electric and magnetic fields. Mutat. Res. 297: 61-95.

- Kavet, R. and Rafferty, C. 1997. Testing EMF for potential carcinogenic activity: a critical review of animal models. Environ. Health Perspect. 105: 81-103.

McDowall, M. E. 1983. Leukemia mortality in electrical workers in England and Wales. Lancet 1: 246.

Michaelson, S. M. 1987. Influence of power frequency electric and magnetic fields on human health. Ann. N.Y. Acad. Sci. 502: $55-57$.

Milham, S. 1985. Silent keys: leukemia mortality in amateur radio operators. Lancet 1: 812.

Mitelman, F. 1991. Catalog of Chromosome Aberrations in Cancer, 4th ed. New York, A. R. Liss.

Miyakoshi, J., Kitagawa, K. and Takeba, H. 1997. Mutation induction by high-density, 50-Hz magnetic fields in human MeWo cells exposed in the DNA synthesis phase. Int. J. Radiat. Biol. 71: 75-79.

- Yamagishi, N., Ohtsu, S., Mohri, K. and Takeba, H. 1996. Increase in hypoxanthine-guanine phosphoribosyl transferase gene mutations by exposure to high-density 50-Hz magnetic fields. Mutat. Res. 349: 109-114.

Murphy, J. C., Kaden, D. A., Warren, J. and Sivak, A. 1993. Power frequency electric and magnetic fields: a review of genetic toxicology. Mutat. Res. 296: 221-240.

Nordenson, I. K., Mild, H., Andersson, G. and Sandstrom, S. 1994. Chromosomal aberrations in human amniotic cells after intermittent exposure to fifty Hertz magnetic fields. Bioelectromagnetics 15: 293-301.

-, - , Nordstrom, S., Sweins, A. and Birke, E. 1984. Clastogenic effects in human lymphocytes of power frequency electric fields: In vivo and in vitro studies. Radiat. Environ. Biophys 23: 191-201.

-, - , Ostman, U. and Ljungberg, H. 1988. Chromosomal effects in lymphocytes of 400-kv substation workers. Radiat. Environ. Biophys. 27: 39-47.

Paile, W., Jokela, K., Koivistoinen, A. and Salomaa, S. 1995. Effects of $50 \mathrm{~Hz}$ sinusoidal magnetic fields and spark discharges on human lymphocytes in vitro. Bioelectrochem. Bioenergetics. 36: 15-22

Pearce, N. E., Sheppard, R. A., Howard, J. K., Fraser, J. and Lilley, B. M. 1985. Leukemia in electrical workers in New Zealand. Lancet 1: 811-812.

Pedersen, B., Koch, J., Bendix Hansen, K., Hindkjaer, J. and Lindbjerg, C. 1997. The monosomy 7 clone in interphase and metaphase cell population: a combined chromosome and primed in situ labeling study. Acta Haematol. 97: 216221.

Pierre, R. V. and Hoagland, H.C. 1971. 45,X cell lines in adult men: Loss of Y chromosome, a normal aging phenomenon?. Mayo. Clin. Proc. 46: 52-55.

— and - 1972. Age-associated aneuploidy: Loss of Y chromosome from human bone marrow cells with aging. Cancer 30: 889-894.

Rosenthal, M. and Obe, G. 1989. Effects of 50-Hertz electromagnetic fields on proliferation and on chromosomal aberrations in human peripheral lymphocytes untreated or pretreated with chemical mutagens. Mutat. Res. 210: 329335.

Saalman, E., Onfelt, A. and Gillstedt-Hedman, B. 1991. Lack of c-mitotic effects in V79 Chinese hamster cells exposed to 50-Hz magnetic fields. Bioelectrochem. Bioenergetics 26: 335-338.

Sauer, T., Beraki, K., Jebsen, P. W., Ormerod, E. and Naess, O. 1998. Numerical aberrations of chromosome 17 in interphase cell nuclei of breast carcinoma cells: lack of correlation with abnormal expression of p53, neu and nm23 protein. APMIS 106: 921-927.

Savitz, D. A. and Calle, E. E. 1987. Leukemia and occupational exposure to electromagnetic fields: Review of epidemiological surveys. J. Occup. Med. 29: 47-51.

—, Watchtel, H., Barnes, F., John, E. and Tvrdik, J. 1988. Case control study of childhood cancer and exposure to 60-Hertz magnetic fields. Am. J. Epidemiol. 128: 21-38.

Scarfi, M. R., Bersani, F., Cossarizza, A., Monti, D., Castellanni, G., Cadossi, R., Franceschetti, G. and Franceschi, C. 1991. Spontaneous and mitomycin-c-induced micronuclei in human lymphocytes exposed to extremely low frequency pulsed magnetic fields. Biochem. Biophys. Res. Commun. 176: 194-200.

-, Granceschetti, G. and Lioi. M. B. 1989. Some results on the cytogenetic effects of low-frequency fields in lymphocytes, Alta. Freq. 58: 337-339.

-, Lioi, M. B., Zeni, O., Franceschetti, G., Franceschi, C. and Bersani, F. 1994. Lack of chromosomal aberrations and micronucleus induction in human lymphocytes exposed to pulsed magnetic fields. Mutat. Res. 306: 1129-1133.

Speers, M. A., Dobbins, J. D. and Miller, V. S. 1988. Occupational exposures and brain cancer mortality: A preliminary 
study of East Texas (USA) residents. Am. J. Ind. Med. 13: 629-638.

Tabrah, F. L., Mower, H. F., Batkin, S. and Greenwood, B. P. 1994. Enhanced mutagenic effect of a $60 \mathrm{~Hz}$ time-varying maagnetic field on numbers of azide-induced TA 100 revertant colonies. Bioelectromagnetics 15: 85-93.

Takahashi, K., Kaneko, I., Date, M. and Fukada, E. 1987. Influence of pulsing electromagnetic fields on the frequency of sister-chromatid exchanges in cultured mammalian cells. Experientia. 43: 331-332.

Terada, R., Yasutake, T., Yamagushi, E., Hisamatsu, T., Nakamura, S., Ayabe, H. and Tagawa, Y. 1999. Higher frequencies of numerical aberrations of chromosome 17 in primary gastric cancers are associated with lymph node metastasis. J. Gastroenterol. 34: 11-17.

Theriault, G. P. 1991. Health Effects of Electromagnetic Radiation on Workers: Epidemiologic Studies. In: Bierbaum, P. J. and Peters, J. M. (eds.). Proceedings of the Scientific Workshop on the Health Effects of Electric and Magnetic Fields on Workers, Cincinnati, US, Department of Health and Human Services, National Institute For Occupational Safety and Health. pp. 91-124.

Thomas, T. L., Stolly, P. D., Stemhagen, A., Fontham, E. T. H., Bleecker, M. L., Stewart, P. A. and Hoover, R. N. 1987. Brain tumor mortality risk among men with electrical and electronics jobs: A case-control study. J. Nat. Can. Inst. 79: 233-238.

Tofani, S., Ferrara, A., Anglesio, L. and Gilli, G. 1995. Evidence for genotoxic effects of resonant ELF magnetic fields. Bioelectrochem. Bioenergetics 36: 9-13.

van Dekken, H. and Alers, J. 1993. Loss of chromosome Y in prostatic cxancer, but not in stromal tissue. Cancer Genet. Cytogenet. 66: 131-132.

—, Pizzolo, J. G., Reuter, V. E. and Melamed, M. R. 1990a. Cytogenetic analysis of human solid tumors by in situ hybridization with a set of 12 chromosome-specific DNA probes. Cytogenet. Cell Genet. 54: 103-107.

—, - Kelsen, D. P. and Melamed, M. R. 1990b. Targeted cytogenetic analysis of gastric tumors by in situ hybridization with a set of chromosome-specific DNA probe. Cancer 66: 491-497.

Wang, B., Yin, P. and Kong, L. 1997. A cytogenetic study on colorectal carcinoma. Chung Hua Ping Li Hsueh Tsa Chih 26: 218-221.

Wyandt, H. E., Chinnappan, D., Ioannidou, S., Salama, M. and O'Hara, C. 1998. Fluorescence in situ hybridization to assess aneuploidy for chromosome 7 and 8 in hematologic disorders. Cancer Genet. Cytogenet. 102: 114-124.

Zwingelberg, R., Obe, G., Rosenthal, M., Mevissen, M., Buntenkotter, S. and Loscher, W. 1993. Exposure of rats to a 50-Hz, 30-mt magnetic field influences neither the frequencies of sister-chromatid exchanges nor proliferation characteristics of cultured peripheral lymphocytes. Mutat. Res. 302: 39-44. 